\title{
Public Transport Accessibility for People with Disabilities
}

\author{
Endang Sri Wahyuni'), Bhisma Murti ${ }^{2)}$, Hermanu Joebagio ${ }^{3)}$ \\ 1) Department of Occupational Therapy, Health Polytechnic Surakarta \\ 2)Masters Program in Public Health, Sebelas Maret University, Surakarta \\ 3) Department of Teaching and Educational Science, Sebelas Maret University, Surakarta
}

\begin{abstract}
Background: Data from the Ministry of Social Services Republic of Indonesia Social Ministry in 2009 showed there were 1,541,942 people with disability in the Indonesian population. Problems often arise regarding access to public-transportation services for people with disability. Despite the existence of UU No 4 in 1997 and UU No 25 in 2009 on accessibility for people with disability, public transport seemed to be poor for them. This study aimed to determine the public transport accessibility for people with disabilities and to provide alternative solutions.

Subjects and Methods: This was a qualitative explorative study. Data were obtained from people with physical and mental disability, and provider (Division Head, Surakarta Public Transport Service Bureau). Data were analyzed using triangulation.

Results: The local government of Surakarta has provided some transport facilities. However, these transport facilities are in low standard and non-accessible to people with disability. Transportation accessible to people with disability is not of priority. According to the provider this was because of limited budget. Consultation and coordination amongst the providers were on going in order to provide better transportation system accessible to people with disability.

Conclusion: Transportation system was not accessible to people with disability. But the government provider in charge of transportation is planning to provide transportation system to people with disability.
\end{abstract}

Keywords: transportation, facility, accessibility, disability, public services transportation.

Correspondence:

Endang Sri Wahyuni. Department of Occupational Therapy, Health Polytechnic Surakarta.

\section{BACKGROUND}

For the general population, disability is deemed "not normal" that makes a bad stigma in the community. The stigma adversely affects the appreciation of the capabilities and skills possessed and incite pity because they will burden the environment. Though they really need is the recognition of equality of opportunity and the rights of the environment, and not pity or mercy alone (State RI, 2009; Colbran, 2010; Kusumaningtyas, 2014).

Data regarding persons with disabilities cannot be known with certainty because people still exist that cannot be open with this condition and tend to be hidden from the environment. Ministry of Social
Affairs of the Republic of Indonesia (2002) says that the total number of people with disabilities in Indonesia reached as many as 1,541,942 people. In Surakarta, persons with disabilities around 1,237 people (Dispendapil Surakarta, 2012).

The problems that arise are persons with disabilities have difficulty in accessing public services in their daily life activities (Rahayu et al., 2013). Yet they are also an Indonesian citizen who has the status, obligations, and rights to acquire equity equal to other citizens in Pancasila and the 1945.

Constitution, therefore, the government should provide care, protection, and facilities for persons with disabilities, including the accessibility of public services 
particularly in the field of public transport with the aim of improving the quality of life of persons with disabilities is based on the principle of equality/ equal opportunity and participation in various aspects of life and living, especially with regard to accessibility, rehabilitation, employment, health and education (Dwiyanto, 2008; Firdaus and Iswahyudi, 2008).

However, the reality in the community showed different circumstances. Access means public services needed by persons with disabilities is still very limited. Constraints, usually associated with architecttural barriers which are difficult to access by persons with disabilities so that they lose the right to get the service (Tarsidi, 2008).

Actually, the Government has promised ease of accessibility for persons with disabilities in Law No. 4 of 1997 and Law No. 25 of 2009 on public services set explicitly that the public service must have some principles that instructs the ease of accessibility to persons with disabilities (State RI, 2009) and supported the Surakarta City Regulation No. 2 of 2008 on Equality of People with Disabilities (Surakarta municipal government, 2008). However, in reality it is far from the availability of disabled-friendly facilities and infrastructure so that they lose their right to obtain similar services.

From the description above, this study is very important in order to analyze more about the accessibility of public services for the fulfillment of the rights of persons with disabilities in the field of public transport in the city of Surakarta.

The study focus on accessibility from the perspective of service users (user) while the barriers viewed from the perspective of the service provider (provider). Providers and users are expected to collaborate in realizing the disability-friendly public transport services are able to meet safety, convenience, usability, and independence for persons with disabilities after seeing the public transport service in the city of Surakarta.

\section{SUBJECTS AND METHODS}

This research is a qualitative exploratory strategy case study approach. The case is the condition of public services in the field of land freight transport (Bus Batik Solo Trans) related to the accessibility of persons with disabilities, barriers and alternative solutions providers that can be applied to public transport in the city of Surakarta. Data collection techniques such as interviews, observation and study of documents (photos and videos). For the validity of the data the researchers used triangulation of data sources, methods and theories.

The informants are manual (with disabilities physically disabled, speech impaired, visually impaired, and mental) in Surakarta using Batik Solo Trans Bus and providers namely Transportation Agency in this case the Head of Transport People Surakarta.

\section{RESULTS}

The level of accessibility of public transport services to persons with disabilities presented in Figure 1. The detailed characteristics of the informant can be seen in Table 1.

A value of indicates that the public transportation component can't be accessed properly, the value of 20 indicates that the components of public transport is less accessible to persons with disability, a value of 40 means that the components of public transport difficult to access, the value of 60 means that the components of public transportation can be accessed either by persons with disabilities, the value of 80 if, as well as the value of 100 indicates that 
persons with disabilities can be very easy access to public transportation component.
Table 2 shows summary of public transport accessibility.

\section{Table 1. Characteristics of research informants}

\begin{tabular}{cccccc}
\hline Informants & Status & Age (Year) & Gender & Occupation & Disability Type \\
\hline 1 & User & 19 & Male & Student & Tuna laras \\
2 & User & 20 & Male & Student & Tuna laras \\
3 & User & 26 & Male & Employee & mentally disabled \\
4 & User & 26 & Male & College Student & Tuna netra \\
5 & User & 30 & Female & Employee & Mentally disabled \\
6 & User & 35 & Female & Teacher & Deaf \\
7 & User & 39 & Female & Employee & Deaf \\
8 & User & 40 & Female & Employee & Speech impaired \\
9 & User & 40 & Female & Teacher & Tuna daksa \\
10 & User & 43 & Male & Craftsmen Pottery & Tuna daksa \\
11 & User & 44 & Female & Teacher & Visually impaired \\
12 & User & 45 & Female & Employee & speech impaired \\
13 & User & 46 & Male & Employee & Visually impaired \\
14 & User & 46 & Female & Psychologist & Tuna daksa \\
15 & User & 48 & Male & Teacher & Tuna daksa \\
16 & User & 50 & Female & Employee & speech impaired \\
17 & User & 59 & Female & Teacher & Visually impaired \\
18 & Provider & 35 & Male & Transport Servicer & Tidak ada \\
\hline
\end{tabular}

\section{Table 2. Summary of accessibility}

\begin{tabular}{|c|c|c|c|}
\hline $\begin{array}{l}\text { Transportation } \\
\text { Service Study based } \\
\text { on UU }\end{array}$ & $\begin{array}{l}\text { Service Currently } \\
\text { Existing }\end{array}$ & $\begin{array}{l}\text { Services Needs (User } \\
\text { Perspective) }\end{array}$ & $\begin{array}{l}\text { Expectation and Follow } \\
\text { Up }\end{array}$ \\
\hline $\begin{array}{l}\text { A. Permen PU No. } \\
\text { 30/PRT/M/2006 } \\
\text { about Technical } \\
\text { Guidelines on the } \\
\text { Facilities and } \\
\text { Accessibility in } \\
\text { Buildings and the } \\
\text { Environment } \\
\text { B. Perda Kota } \\
\text { Surakarta No } 2 \\
\text { Tahun 2008 about } \\
\text { on Equality of } \\
\text { Citizens with } \\
\text { Disabilities }\end{array}$ & $\begin{array}{l}\text { 1. Terminal: } \\
\text { 2. Floor of Ceramic } \\
\text { 3. No special track for } \\
\text { terminal access } \\
\text { 4. Need Assistance } \\
\text { 5. Many Stairs } \\
\text { 6. Ramp does not } \\
\text { standardized } \\
\text { 7. No special parking for } \\
\text { people with } \\
\text { disabilities } \\
\text { 8. No worker can speak } \\
\text { cues } \\
\text { 9. Limitation of guideline } \\
\text { and traffic sign } \\
\text { facilities } \\
\text { 10.Difficult access to } \\
\text { Public Facilities (toilet } \\
\text { dan mosque) } \\
\text { Autobus: } \\
\text { 1. Door slippery material } \\
\text { 2. Autobus door can't } \\
\text { snuggle Shelter }\end{array}$ & $\begin{array}{l}\text { Physical disability: } \\
\text { a. Room with floor anti- } \\
\text { slip and non-slip } \\
\text { b. Door with spacious } \\
\text { min } 90 \mathrm{~cm} \\
\text { c. Special lanes and } \\
\text { ramps } \\
\text { d. Ramp } \\
\text { sizestandardized 1:12 } \\
\text { e. Special parking with } \\
\text { Wheelchair } \\
\text { f. Spacious room to } \\
\text { access the wheelchair } \\
\text { g. Chairandhandrail } \\
\text { standard Design } \\
\text { h. The surface of the } \\
\text { floor / space ramps } \\
\text { and flat }\end{array}$ & $\begin{array}{l}\text { - Sosialisasi peraturan } \\
\text { dan standar yang lebih } \\
\text { sering kepada arsitek, } \\
\text { Dinas PU \& Dinas } \\
\text { Perizinan Bangunan di } \\
\text { daerah-daerah, dan } \\
\text { masyarakat melalui } \\
\text { institusi (Dep. PU, } \\
\text { Ikatan Arsitek } \\
\text { Indonesia, dll), dan } \\
\text { media massa. } \\
\text { - Standaraksesibilitas } \\
\text { dijadikan bagian yang } \\
\text { diaudit dalam } \\
\text { perizinan membangun } \\
\text { bangunan gedung atau } \\
\text { fasilitas } \\
\text { publik lainnya. } \\
\text { - Penerapan prinsip } \\
\text { Universal Design } \\
\text { - Penegakan hukum } \\
\text { dengan sanksi yang } \\
\text { jelas } \\
\text { - Clear and easy report }\end{array}$ \\
\hline
\end{tabular}


Journal of Health Policy and Management(2016), 1(1): 1-7

https://doi.org/10.26911/thejhpm.2016.01.01.01

\begin{tabular}{|c|c|c|c|}
\hline $\begin{array}{l}\text { D. Free Provisioning } \\
\text { Accessibility in } \\
\text { Buildings and } \\
\text { Environment, } \\
\text { Institute of Social } \\
\text { Services } \\
\text { DisabilityDisability, } \\
\text { Ministry of Social } \\
\text { Affairs 2005 } \\
\text { E. Kemen PU No. } \\
\text { 441/ KPTS/ 1998 } \\
\text { about technical re- } \\
\text { quirements and } \\
\text { environmental } \\
\text { public buildings }\end{array}$ & $\begin{array}{l}\text { 3. Short seat with high } \\
\text { handle } \\
\text { 4. Wheelchair } \\
\text { impassable } \\
\text { 5. Limitations signs for } \\
\text { directions when the } \\
\text { door opens and closes } \\
\\
\text { Shelter: } \\
\text { 1. The narrow and steep } \\
\text { of shelter door } \\
\text { 2. Material lantai shelter } \\
\text { licin } \\
\text { 3. Too high stairs } \\
\text { 4. Steep and narrow } \\
\text { ramp } \\
\text { 5. Shelter space less } \\
\text { extensive } \\
\text { 6. Limitation of sign in } \\
\text { shelter (dysfunction } \\
\text { running text) } \\
\text { Pedestrian: } \\
\text { 7. Spaces use to trading, } \\
\text { parking, and } \\
\text { gardening } \\
\text { 8. Limitation of ramp } \\
\text { 9. Limitation signs for } \\
\text { people with disability } \\
\text { 10. Height and level } \\
\text { uneven surface } \\
\text { flatness } \\
\text { 11. Not all are equipped } \\
\text { pedestrian bollards as } \\
\text { a differentiator } \\
\text { between the curb and } \\
\text { sidewalk } \\
\text { 12. There are still trees, } \\
\text { signs and } \\
\text { complementary } \\
\text { objects blocking the } \\
\text { way } \\
\text { 13. There is a ditch that is } \\
\text { not covered } \\
\text { 14. There are garden } \\
\text { chairs facility } \\
\text { chang }\end{array}$ & $\begin{array}{l}\text { b. Clearly speakers } \\
\text { c. Prevention of } \\
\text { auditorium lighting } \\
\text { auditorium yang } \\
\text { tepat untuk membaca } \\
\text { gerak bibir } \\
\text { d.Petugas yang dapat } \\
\text { berbahasa isyarat } \\
\\
\text { Disabilitas netra: } \\
\text { a. Rambu penanda } \\
\text { berupa suara/taktil } \\
\text { (Braille). Bagi low } \\
\text { vision, tulisan } \\
\text { dengan warna dan } \\
\text { ukuran jelas dan } \\
\text { besar } \\
\text { b.Rintangan di jalan } \\
\text { perlu disingkirkan } \\
\text { c. Petunjuk arah } \\
\text { pergantian } \\
\text { permukaan jalan } \\
\text { yang tegas } \\
\text { d.Jalur khusus, } \\
\text { permukaan rata dan } \\
\text { landai } \\
\text { Disabilitas mental: } \\
\text { a.Petunjuk dan rambu- } \\
\text { rambu yang jelas dan } \\
\text { baku } \\
\text { b.Bangunan yang aman } \\
\text { dengan sudut tumpul }\end{array}$ & $\begin{array}{l}\text { - Controlling and } \\
\text { supervising } \\
\text { bystakeholders } \\
\text { - Coaching the } \\
\text { counseling } \\
\text { accessibility } \\
\text { transportation services } \\
\text { operator. } \\
\text { (driver, } \\
\text { stewardess/setc.) } \\
\text { - Untuk perencanaan } \\
\text { terminal/halte baru } \\
\text { harus merujuk pada } \\
\text { peraturanperaturan } \\
\text { dan standar } \\
\text { aksesibilitas yang } \\
\text { telah ada } \\
\text { - Terminal yang telah } \\
\text { ada dan belum } \\
\text { aksesibel harus segera } \\
\text { disempurnakan dan } \\
\text { dilengkapi dengan } \\
\text { fitur yang dapat } \\
\text { menghilangkan } \\
\text { hambatan aksesibilitas } \\
\text { tersebut } \\
\text { Bus yang } \\
\text { dipergunakan diganti } \\
\text { dengan berlantai datar } \\
\text { atau low floor bus } \\
\text { dengan standar } \\
\text { aksesibilitas yang } \\
\text { ainnya (seperti lebar } \\
\text { pintu, ruang khusus } \\
\text { kursi roda, dll) atau } \\
\text { menyediakan bus } \\
\text { khusus yang aksesibel } \\
\text { dan jadwal khusus } \\
\text { pelayanan } \\
\text { - Variasi metode } \\
\text { penyampaian } \\
\text { informasi dan } \\
\text { kelengkapan rambu } \\
\text { disediakan } \\
\text { - Memberikan } \\
\text { sosialisasi dan } \\
\text { pelatihan standar } \\
\text { pelayanan bagi } \\
\text { penyandang } \\
\text { disabilitas kepada } \\
\text { pengelola dan staf } \\
\text { terminal, bus, dan } \\
\text { lain-lain. }\end{array}$ \\
\hline
\end{tabular}




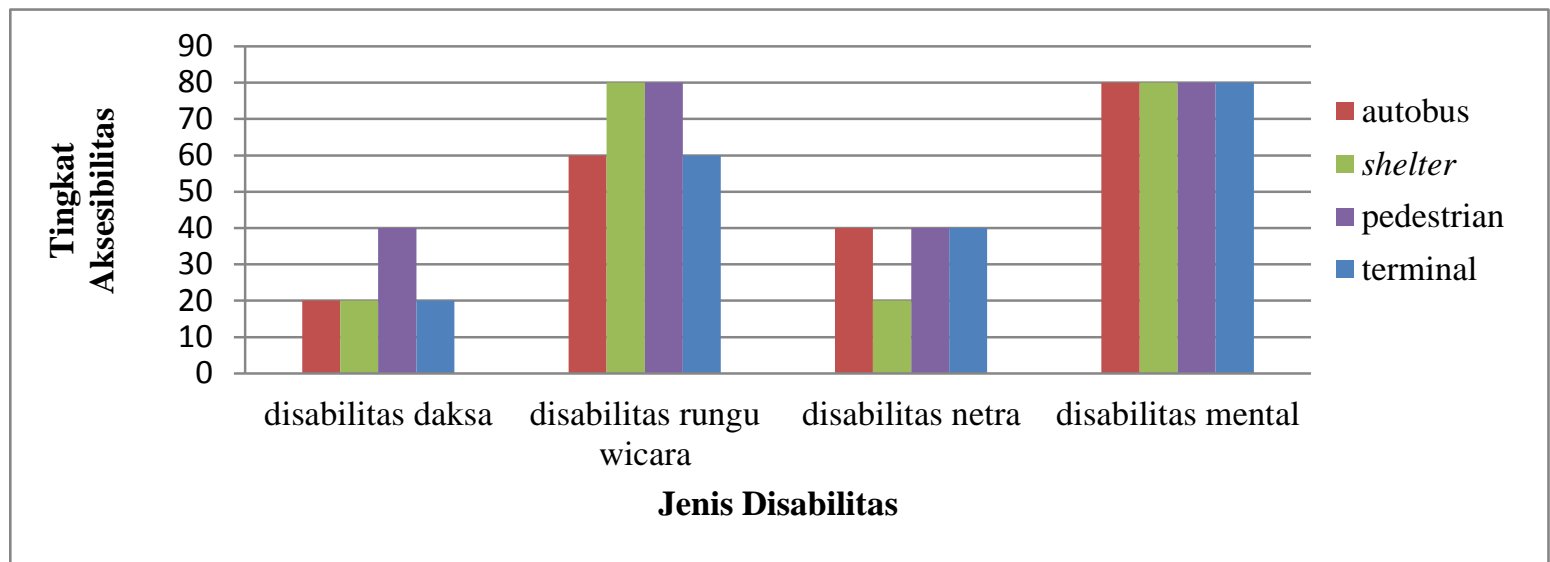

Figure 1. Diagram of the Public Transport Accessibility Services Disability

\section{DISCUSSION}

1. User

a. Disability physically disabled

Problems faced by physically disabled persons with disabilities in accessing public transport services, can be caused by environmental conditions that are less accessible and safe for safety. This is similar to Tarsidi (2008) which suggests that the barrier for wheelchair users is due to architectural design.

b. Disability impaired speech

For persons with disabilities impaired speech, faces obstacles in terms of: the limited facilities guide/ concierge who can speak cues and signposts the directions that are not fully guaranteed safety in use/ access independently. The condition is consistent with the statement that the barriers experienced by deaf, include difficulty in lip-read in the auditorium in bad lighting and listen to the sound of the alarm (Tarsidi, 2008). The statement was supported Aryani (2010), which explained that the hearing impaired, the information can be provided through the visual senses, such as using fire warning bell, their lights flickering, sign language, and running text. Public Disclosure Authorized (2013) suggested when using the running text, the writing should be large enough so that people can read clearly. When using text rotates, the article should not move too quickly so easy to read.

c. Disability impaired

Barriers visual disability include difficulty in architectural buildings and limited facilities signposts user such as voice or tactile. In accordance with the conditions Syafi'e (2012), which states that for the blind, which is most needed is an audio system, such as talking shops, architecture containing Braille on the handle stairs, warning block on public roads, in braille keyboard, mobile point, and so forth. Public Disclosure Authorized (2013) recommends that the blind must be provided tactile information (Braille or tactile signs at bus shelters and terminals) to help access information on transport services.

d. Mental disability

In persons with mental disabilities, not many obstacles if there is raw and clear instructions. They can mimic, look, ask questions, and follow the example of activities to do. This is in line with the opinion of Tarsidi (2008), which states that the architectural barriers faced by persons with mental disabilities, such as difficulty in finding a way in a new environment where 
there are no clear instructions and standard way. In addition, it is preferred for persons with mental disabilities is safety, so that it takes is making buildings with an obtuse angle (Aryani, 2010).

\section{Provider}

\section{a. Barriers government Surakarta}

Some of the barriers experienced by Dishubkominfotrans, Surakarta City Government in providing services Bus Batik Solo Trans-friendly for persons with disabilities in this study, namely: the lack of commitment of local government to provide services in accordance with the standards and the lack of focus of the central government towards public transport services, the implementation of transport policy is less precise, the lack of support from parties/ institutions, the notion that transportation is not an issue of priority, the limited allocation of funds for the transport sector so that special services for persons with disabilities has not been a top priority in the provision and development of existing infrastructure.

In the book source Poverti Reduction written by the World Bank (2002), provides guidance for countries in the strategy to develop and strengthen poverty reduction by stressing the importance of a good guideline for policy planning and decision making as well as maintaining the accessibility of the environment for all people, including persons with disabilities (Meriläinen and Helaakoski, 2001). In the Cities on the Move written by The World Bank (2001), emphasizing the application of the principles of accessibility for all in both the road and the design of buildings and other public facilities to cover all the needs for access to strategic problems, especially for the disabled.

b. Alternative solutions

Alternative solutions that have been made include consultation with PPRBM and coordinate with other agencies that are involved in building infrastructure, implementing SOP rapit transit system and build portable shelters in places with limited space. The move is in line with what is emphasized by the World Bank (2001), which emphasizes the importance of cooperation between national and international institutions to strengthen the data needs (on the scale and nature) as well as accessibility and mobility barriers faced by persons with disabilities and the elderly.

\section{REFERENCES}

Aryani D, Rosinta F (2010). Effect of Service Quality on Customer Satisfaction in Shaping Customer Loyalty. Journal of Administrative Sciences and Organizations.17(2).

Colbran N (2010). Access to Justice Disability Indonesia.

Dwiyanto A (2008). Public Bureaucracy Reform in Indonesia. Yogyakarta: Gadjah Mada University Press.

Firdaus F, Iswahyudi F (2010). Accessibility in Public Services for People with Special Needs. 6(3).

Kusumaningtyas (2014). Knowing and Understanding. Further People with Disabilities: Focus Issue 45.

RI State Institutions (1997). Law No. 4 of 1997 on The Disabled.

(2009). Law No. 25 of 2009 on Public Service.

Merilainen, Helaakoski (2001). Transport, Poverty and Disability in Developing Countries. Technical Note Prepared for The Poverty Reduction Sourcebook. Washington DC: The World Bank.

Surakarta City Regulation No. 2 of 2008 on Equality of People with Disabilities.

Public Disclosure Authorized (2013). Improving Accessibility to Transport for People with Limited Mobility (PLM). 
A Practical Guidance Note. Middle East and North Africa Region: Sustainable Development Department.

Rahayu S, Goddess U, Ahdiyana M. (2013). Public Services for Transportation for People with Disabilities in The Province of Yogyakarta. Asian Iii National Symposium Semarang: 14-15.

Syafi'e M (2012). Disability Accessibility Images in Yogyakarta. Solider News Indonesia Disabilities: June 27, 2012.
Tarsidi D (2008). Role of Parents in Children's Social Competence Development. Indonesian Education University (UPI).

The World Bank (2001). Cities on The Move: A World Bank Urban Transport Strategy Review. Private Sector Development and Infrastructure Transport. Washington, DC, USA: The World Bank. 